inhibition of presynaptic cholinergic signaling by stimulation of presynaptic muscarinic type 2 receptors and nonphysiologic, tonic stimulation of postsynaptic nicotinic and muscarinic receptors. ${ }^{6}$ Despite these limitations, mobility benefits of AChEIs have been reported in PD.?

Preliminary data in animal studies suggest that drugs that selectively stimulate $\alpha 4 \beta 2\left(^{*}\right)$ nicotinic receptors not only have excellent entry into the brain but also may improve mobility functions in rats with dual dopaminergic and cholinergic lesions. ${ }^{8}$ Such selective agonists are superior to the nonselective nicotine mother drug because nicotine interferes with the phasic cholinergic activity that is essential for cognitive function. ${ }^{9}$ Further investigation of this class of drugs to treat mobility problems in PD is necessary.

(C) 2014 American Academy of Neurology

1. Bohnen NI, Frey KA, Studenski S, et al. Gait speed in Parkinson disease correlates with cholinergic degeneration. Neurology 2013;81:1611-1616.

2. Potter-Nerger M, Volkmann J. Deep brain stimulation for gait and postural symptoms in Parkinson's disease. Mov Disord 2013;28:1609-1615.
3. Assal F, Allali G, Kressig RW, et al. Galantamine improves gait performance in patients with Alzheimer's disease. J Am Geriatr Soc 2008;56:946-947.

4. Montero-Odasso M, Wells J, Borrie M. Can cognitive enhancers reduce the risk of falls in people with dementia? An open-label study with controls. J Am Geriatr Soc 2009;57:359-360.

5. Bohnen NI, Kaufer DI, Hendrickson R, et al. Degree of inhibition of cortical acetylcholinesterase activity and cognitive effects by donepezil treatment in Alzheimer's disease. J Neurol Neurosurg Psychiatry 2005;76:315-319.

6. Hasselmo ME, Sarter M. Modes and models of forebrain cholinergic neuromodulation of cognition. Neuropsychopharmacology 2011;36:52-73.

7. Litvinenko IV, Odinak MM, Mogil'naya VI, et al. Efficacy and safety of galantamine (reminyl) for dementia in patients with Parkinson's disease (an open controlled trial). Neurosci Behav Physiol 2008;38:937-945.

8. Kucinski A, Paolone G, Bradshaw M, et al. Modeling fall propensity in Parkinson's disease: deficits in the attentional control of complex movements in rats with cortical-cholinergic and striatal-dopaminergic deafferentation. J Neurosci 2013; 33:16522-16539.

9. Howe WM, Ji J, Parikh V, et al. Enhancement of attentional performance by selective stimulation of alphałbeta2 $(*)$ nAChRs: underlying cholinergic mechanisms. Neuropsychopharmacology 2010;35:1391-1401.

\title{
CORRECTION
}

\section{Tumefactive MS lesions under fingolimod: A case report and literature review}

In the article "Tumefactive MS lesions under fingolimod: A case report and literature review" by G. Pilz et al. (Neurology ${ }^{\circledR}$ 2013;81:1654-1658), there is an error in the description of figure B.c. The description should have read, "Follow-up MRI 6 months later: a new large T2 hyperintense lesion with perifocal edema is seen in the right frontal white matter which shows ring-like gadolinium enhancement (lower panel)." The authors regret the error. 


\section{Neurology}

\section{Tumefactive MS lesions under fingolimod: A case report and literature review Neurology 2014;82;1569 \\ DOI 10.1212/WNL.0000000000000442}

\section{This information is current as of April 28, 2014}

Updated Information \&

Services

Permissions \& Licensing

Reprints including high resolution figures, can be found at: http://n.neurology.org/content/82/17/1569.full

Information about reproducing this article in parts (figures,tables) or in its entirety can be found online at:

http://www.neurology.org/about/about_the_journal\#permissions

Information about ordering reprints can be found online:

http://n.neurology.org/subscribers/advertise

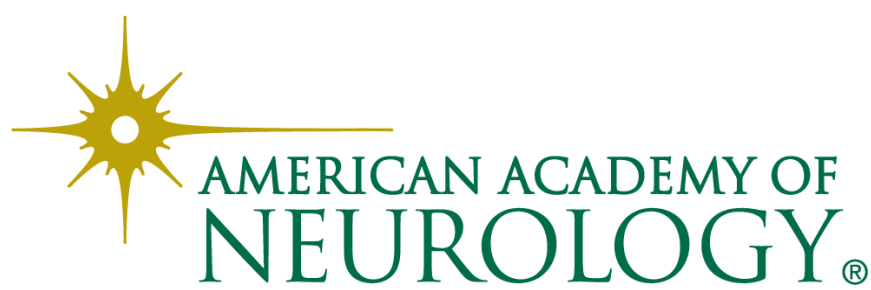

